\title{
INOVASI PEMANFAATAN SAYURAN MENJADI SMOOTHIE DAN ICE CREAM SAYUR
}

\author{
Nila Widayanti ${ }^{(1)}$, Santa Maimurni ${ }^{(2)}$, Dita Sari Mulyadi ${ }^{(3)}$, Noviana Dwi Putri Ratnasari ${ }^{(4)}$, \\ Siti Aisyah $^{(5)}$ dan Nukmatus Syahria ${ }^{(6)}$ \\ ${ }^{(1,2)}$ Fakultas Keguruan dan Ilmu Pendidikan, Universitas PGRI Adi Buana Surabaya \\ (3,4) Fakultas Ekonomi, Universitas PGRI Adi Buana Surabaya \\ ${ }^{(5)}$ Fakultas Teknik, Universitas PGRI Adi Buana Surabaya \\ ${ }^{(6)}$ Dosen Pendidikan Bahasa Inggris, Fakultas Keguruan dan Ilmu Pendidikan \\ Universitas PGRI Adi Buana Surabaya \\ Email: ${ }^{(6)}$ syahria@unipasby.ac.id
}

\begin{abstract}
ABSTRAK
Sayur adalah warisan leluhur Indonesia dan secara tradisional dapat dijadikan pengobatan. Sayuran sebagai potensi sumber daya alam Indonesia perlu dilestarikan, dengan cara membuat inovasi baru jaтu dalam bentuk smoothie dengan tujuan untuk meningkatkan manfaat jamu di Indonesia. Kegiatan ini bertujuan untuk menarik orang agar mencintai produk warisan leluhur yang hampir dipinggirkan oleh produk pasar modern belakangan ini. Melalui inovasi baru ini, diharapkan animo masyarakat khususnya Desa Kepuh Kemiri, Tulangan ketertarikannya terhadap jamu dapat meningkat. Penelitian ini dilakukan karena mayoritas masyakat di desa Kepuh Kemiri, Tulangan bekerja sebagai petani penghasil sayuran. Kegiatan penelitian ini dilakukan di beberapa dusun di Desa Kepuh Kemiri, Tulangan yaitu RT.03 dan RT.09, dengan cara sosialisasi produk dan cara kerja produk yang dihasilkan. Hasil penelitian menunjukkan bahwa ada minat yang tinggi dari masyarakat desa Kepuh Kemiri, Tulangan dalam membuat smoothies nabati. Diharapkan mereka dapat mengembangkan inovasi baru dalam pembuatan sayuran sehingga dapat meningkatkan pendapatan rumah tangga.
\end{abstract}

Kata kunci: Sayuran, Smoothies, Inovasi baru

\section{ABSTRACT}

Vegetable is a way of traditional treatment of ancestral heritage that has long been known in Indonesia. Vegetable as a culture of the Indonesian Society desperately needs to be preserved. In an effort to preserve herbs and improve the benefits of herbal medicine in Indonesia, the Division of Work Program "Smoothies vegetable" KKN-PPM group in Kepuh Kemiri Village, Tulamgan made a new innovation in the form of herbal medicine in the form of smoothies. It aims to attract people to love more ancestral heritage products that are almost marginalized by modern market products lately. Through this new innovation, it is expected the interest of the community especially Kepuh Kemiri Village, Tulangan to herbal medicine can increase. Researchers use herbs as an ingredient of smoothies, because some people in the village of Kepuh Kemiri, Tulangan work as a maker of vegetable. This research activity was carried out in several hamlets in Kepuh Kemiri village, Tulangan namely RT.03 and RT.09 The KKM-PPM group activities in each sub-village are done by way of product socialization and how the product works. The results obtained from this research that there is a high interest from the community of Kepuh Kemiri village, Tulangan in making smoothies vegetable. It is expected that they can develop new innovations in the manufacture of vegetable so as to increase household income.

Keywords: Smoothies vegetable, new Innovation 


\section{PENDAHULUAN}

Sayuran merupakan suatu kebutuhan yang harus dipenuhi oleh manusia, melalui pengolahan pengolahan sayuran manusia dapat melangsungkan kehidupannya dengan pola hidup sehat dan teratur. Kurangnya pengolahan sayuran di desa membuat warga desa sering mengeluh merasa sakit di beberapa titik tubuh tertentu. Kurangnya pengolahan sayuran ini dikarenakan mereka tidak memiliki pemahaman tentang bagaimana mengolah sayuran agar bernilai jual tinggi dan mereka malas untuk melakukan inovasi sayuran. Sedangkan pekerja buruh tani jika tidak diimbangi dengan pengolahan sayuran akan berdampak terhadap perekonomian yang stagnan. Untuk meningkatkan perekonomian masyarakat desa, maka penulis berinisiatif untuk memberikan penyuluhan kepada warga desa tentang mengolah sayuran. Kami ingin membuat suatu program kerja yaitu Smooties Sawi dan ice cream sayur, yang dimaksudkan untuk dapat menjadi wadah bagi warga desa besama-sama dalam melaksanakan pengolahan-pengolahan sayuran yang dapat membuat mereka menjadi sehat dan dapat menjadi komoditas utama di Desa Kepuh Kemiri, selain itu juga dapat meningkatkan perekonomian masyarakat desa.

Smooties sawi merupakan program yang dijalankan untuk menggerakkan warga desa agar warga desa sehat dan meningkatkan perekonomian. Smootiesh sawi ini dapat dilakukan dengan berbagai cara salah satunya yaitu dengan pengolahan sayuran yang ditambahkan dengan tape, SKM, dan gula untuk menghasilkan rasa yang berbeda. Smootiessawi adalah suatu pengolahan sayuran yang dijadikan minuman yang bermanfaat bagi kesehatan tubuh.

Es krim adalah produk pangan beku yang dibuat melalui kombinasi proses pembekuan dan agitasi pada bahan-bahan yang terdiri dari susu dan produk susu, pemanis, penstabil, pengemulsi, serta penambah citarasa (flavor). Es krim biasa dikonsumsi sebagai makanan selingan (dessert) dan dikelompokkan dalam makanan camilan (snack). Prinsip pembuatan es krim adalah membentuk rongga udara pada campuran bahan es krim sehingga diperoleh pengembangan volume yang membuat es krim menjadi lebih ringan, tidak terlalu padat, dan mempunyai tekstur yang lembut (Padaga dan Sawitri, 2005).

Menurut SNI (1995) es krim adalah jenis makanan semi padat yang dibuat dengan cara pembekuan tepung es krim atau dari campuran susu, lemak hewani maupun nabati, gula, dengan atau tanpa bahan makanan lain dan bahan tambahan makanan yang diizinkan.Es krim merupakan hasil pembekuan sebagiansistem buih (foam) yang biasanya mengandung $40-50 \%$ udara $(\mathrm{v} / \mathrm{v})$. Fasekontinyu dari buih tersusun oleh kristal es, partikel padatan terlarut, dankoloidal (garam, protein, gula, dan stabilizer), serta lemak dalam bentukemulsi (Berger, 1976).

Menurut Ismunandar (2004) es krim mempunyai struktur berupa busa yaitu gas yang terdispersi dalam cairan, yang diawetkan dengan pendinginan sampai suhu beku. Es krim tampak sebagai wujud yang padu, tetapi bila dilihat dengan menggunakan mikroskop akan tampak empat komponen penyusun es krim yaitu padatan globula lemak susu, udara yang ukurannya tidak lebih dari $0,1 \mathrm{~mm}$, kirstal-kristal kecil es dan air yang melarutkan gula, garam dan protein susu.

Es krim merupakan suatu hidangan yang berbentuk emulsi air dalam minyak (water in oil).Es krim terdiri dari $62-68 \%$ air, $32-38 \%$ bahan padat dan udara.Menurut Soeparno (1998) dalam Malaka (2007) menjelaskan bahwa es krim adalah sejenis produk makanan beku yang terbuat dari krim susu, gula dengan atau tanpa penambahan zat pembentuk aroma dan mengandung antara 8$14 \%$ lemak susu.

Es krim yang diproduksi oleh industri modern komersial dibuat dari campuran bahan-bahan yaitu 10-16\% lemak susu, 9-12\% padatan tanpa lemak, 12-16\% gula, $0,2-0,5 \%$ stabilizer dan emulsifiers, 55$64 \%$ air yang berasal dari susu atau bahan lain (Anonymous, 2006).

Es cream memiliki kandungan bahan pengawet atau tambahan pewarna lainnya. 
Meskipun tidak semua ice cream seperti itu, ada baiknya pengosumsian dibatasi. Karena makanan dalam kondisi siap saji pun sudah dipastikan belum cukup memiliki kandungan gizi yang maksimal. Selain itu, zat gula pada ice cream mampu membuat kerusakan gigi menjadi keropos. Gula pada ice cream juga dapat berakibat timbulnya penyakit obesitas. Efek dingin pada ice cream juga dapat menimbulkan penyakit amandel, flu, batuk, dan juga radang tenggorokan. Untuk meminimalisir kemungkinan tersebut terjadi, anda bisa membuat ice cream sendiri dirumah dengan menggunakan bahan - bahan yang aman.

Ice cream boleh untuk dikonsumsi, namun tidak secara berlebihan,. Selain memiliki varian rasa yang manis dan terkadang asam dari olahan buah - buahan. Selain berbagai rasa tersebut, ternyata ada juga lho campuran ice cream dari bahan sayuran. Ice cream tersebut bermaksud untuk memanipulasi rasa agar dapat dimanfaatkan anak - anak. Anak - anak biasanya tidak menyukai berbagai jenis sayuran, terutama sayuran hijau. Menurut mereka, sayuran memiliki rasa yang pahit dan tidak enak untuk dikonsumsi. Alhasil, anak - anak kekurangan kandungan dari sayuran. Sayuran merupakan salah satu pelengkap empat sehat lima sempurna.

Nah, jika salah satu pelengkap tidak tercukupi, kesehatan tubuh pun akan terganggu. Untuk menarik minat anak - anak anda dalam mengonsumsi sayuran, dapat melakukan cara dengan mencampurkan olahan ice cream. Salah satunya, menggunakan sawi untuk menarik perhatian warna ice cream.

\section{A. Kegunaan}

Sawi merupakan sayuran yang sangat mudah untuk dijumpai, selain mudah dijumpai ternyata manfaat sawipun cukup banyak. Manfaat sawi yang banyak ini tidak lepas dari kandungan nutrisi yaitu sawi mempunyai kandungan fitonutrien yang mampu mencegah berbagai penyakit. Berikut beberapa manfaat sawi bagi tubuh yang kami himpun melalui berbagai sumber, salah satunya dari Sumber Informasi Gizi :
Berbagai publikasi Kementrian Kesehatan Republik Indonesia serta dari wartamedika.com, maka dapat disimpulkan bahwasannya sawi mempunyai manfaat, yaitu:

1. Mengatasi peradangan dan pembentukan plak di arteri

Manfaat sayur sawiyaitu membantu mengatasi peradangan. Sawi mempunyai kandungan fitonutrien, querecetin yang membantu mengatasi proses peradangandan juga membantu mencegah timbulnya plak didaerah arteri.

2. Membantu mengendalikan kolesterol pada tubuh

Pada sawi hijau mengandung tinggi serat, serat ini membantu mengontrol kadar kolesteroljahat pada darah.

3. Sumber antioksidan

Sawi yang masih dalam keadaan segar merupakan sumber antioksidan yang sangat baik. Selain mengandung antioksidan, sawi ini juga mengandung mineral lain seperti Vitamin A, C, E, karoten, dan juga mineral lain seperti kalsium, zat besi, magnesium, seng, kalium, selenium dan juga mangan.

4. Mencegah Kanker

Sawi mempunyai kandungan klorofil yang tinggi pada daunnya yang berwarna hijau tua. Kandungan klorofil pada sawi ini mampu menghambat efek karsinogenik amina heterosiklik yang muncul saat proses memanggang atau membakar makanan.

5. Mengurangi resiko diabetes tipe 2

Kandungan antioksidan pada sawi bermanfaat sebagai alpha lipoic acid yang mana bermanfaat menurunkan kadar gula dalam darah. Kandungan ini juga meningkatkan sensitivitas insulindan juga mencegah oksidatif stress.

6. Menjaga kesehatan kulit dan rambut Kandungan vitamin A pada sawi sangat bagus untuk kulit. Vitamin A ini diperlukan untuk memprodusi 
sebum yang berfungsi untuk melembapkan rambut. Selain itu, vitamin A ini juga dibutuhkan untuk proses pertumbuhan jaringan tubuh termasuk kulit dan rambut. Kandungan vitamin $\mathrm{C}$ yang cukup tinggi pada sawi bermanfaat untuk membangun dan memelihara kolagen yang mana memberikan struktur pada kulit serta rambut.

7. Mempunyai kandungan vitamin $\mathrm{C}$ yang tinggi

Kandungan vitamin $\mathrm{C}$ pada sawi ternyata jauh lebih tinggi daripada jeruk. Vitamin $\mathrm{C}$ ini berguna untuk menjaga kesehatan kita, mengganti sel sel tubuh yang rusak.

8. Membantu program diet

Sawi mempunyai kandungan kalori yang cukup rendah namun sawi ini mempunyai kandungan serat yang cukup tinggi. Kandungan serat yang tinggi pada sawi membantu melancarkan proes pencernaan kita. Hal inilah yang membuat sawi sangat cocok untuk dijadikan menu andalan diet.

9. Bermanfaat untuk ibu hamil

Sawi mempunyai kandungan asam folat yang cukup tinggi. Asam folat ini membantu proses pertumbuhan dan perkembangan otak janin. Mengkonsumsi sawi saat masa kehamilan sangat disarankan karena tingginya nutrisi yang terkandung pada sawi tersebut.

10. Menjaga kesehatan tulang

Sawi juga mengandung tinggi vitamin K. Vitamin K ini membantu menjaga kesehatan dan massa tulang sehingga dapat mencegah osteoporosis dini.

\section{METODE PELAKSANAAN}

A. Rancangan Kegiatan

Rancangan kegiatan KKN-PPM Kepuh Kemiri yakni dengan melaksanakan sosialisasi pada saat mengadakan rapat PKK. Tim juga melakukan tester kepada warga sekitar balai desa untuk menunjang terlaksananya demo smootie dan ice cream. Demo smootie dan ice cream ini dilaksanakan pada tanggal 13 Februari 2018 pada pukul 09.00 WIB. Berikut rancangan kegiatan smootie dan ice cream sayur.

TEMPAT PELAKSANAAN

KEGIATAN KKN-PPM TIM

"SMOOTHIES SAYUR"

\begin{tabular}{|c|l|c|c|}
\hline $\begin{array}{c}\text { No } \\
\cdot\end{array}$ & Nama RT & $\begin{array}{c}\text { Tanggal } \\
\text { Pelaksanaa } \\
\text { n Kegiatan }\end{array}$ & $\begin{array}{c}\text { Jumlah } \\
\text { Responde } \\
\text { n }\end{array}$ \\
\hline 1 & RT.03 & $\begin{array}{c}3 \text { Februari } \\
2018\end{array}$ & 22 \\
\hline 2 & RT.09 & $\begin{array}{c}3 \text { Februari } \\
2018\end{array}$ & 23 \\
\hline
\end{tabular}

\section{B. Responden}

Responden dalam kegiatan ini adalah ibu-ibu PKK yang terdapat di Desa Kepuh Kemiri, Tulangan, Sidoarjo yang tinggal di beberapa RT yang ada di Desa Kepuh Kemiri, yakni RT.03 dan RT. 09.Dari hasil observasi mahasiswa KKN-PPM ibu-ibu warga RT. 03 dan RT.09 yang aktif dalam berbagai kegiatan. Dari hasil observasi tersebut, kami mengambil 4 subyek untuk dilakukan penelitian, yaitu dua orang dari RT.03 dan dua orang dari RT.09. Terdapat 45 ibu-ibu PKK yang menjadi sasaran kegiatan kelompok "Smoothies Sayur dan Ice Cream Sayur" KKN-PPM Desa Kepuh Kemiri, Tulangan, Sidoarjo.

C. Alat dan Bahan yang Digunakan Untuk Pembuatan Smootie Sayur

Berikut ini adalah rincian alat dan bahan yang digunakan untuk membuat smootie sayur:

Alat:

- Blender

Bahan:

- Sawi

- Tape

- SKM

- Gula

- Es batu yang sudah digeprek

Cara Membuat: 
- Cuci Sawi terlebih dahulu, kemudian potong sawi(gunakan daunnya saja)

- Siapkan blender

- Masukkan semua bahan kedalam blender kemudian blender hingga menjadi lembut dan kental.

Smootie siap disajikan

D. Alat dan Bahan yang Digunakan Untuk Pembuatan Ice Cream Sayur

Berikut ini adalah rincian alat dan bahan yang digunakan untuk membuat ice cream sayur:

Alat:

- Kompor

- Panci

- Pengaduk

- Sendok

- Wadah plastik untuk hasil produk

Bahan:

- Tepung maizena

- Susu kental manis

- Vanili bubuk

- SP

- Gula pasir

- Sari Sayuran Sawi (sesuai dengan selera)

Cara kerja:

- Siapkan bahan-bahan yang akan dimasak (tepung maizena $2 \mathrm{sdt}$, susu kental manis 4sct, vanili bubuk $1 / 2 \mathrm{sdt}$, gula pasir $6 \mathrm{sdm}$, sari jamu $500 \mathrm{ml}$.

- Semua bahan dijadikan satu dan diaduk hingga tercampur. Sebelum dimasak dalam kompor.

- Setelah bahan tercampur, masak semua bahan diatas api kecil hingga meletup-letup. Setelah itu dinginkan.

- Setelah bahan mendingin, masukkan kedalam freezer hingga membeku sebagian.

- Setelah membeku, campur bahan dengan SP, vanili kemudian diaduk dengan mixer sampai mengembang dan berbusa

- Masukkan bahan dalam cup es krim
- $\quad$ Bekukan dalam freezer

E. Teknik Pengumpulan Data

Menurut Sugiyono (2011:224)

mengatakan "Teknik pengumpulan data merupakan langkah yang paling strategis dalam penelitian, karena tujuan utama dari penelitian ini adalah mendapatkan data". Dalam penelitian ini, adapun metode pengumpulan data adalah sebagai berikut :

1. Kuisioner

Pengertian metode angket menurut Arikunto (2006:151) "Angket adalah pernyataan tertulis yang digunakan untuk memperoleh informasi dari responden dalam arti laporan tentang pribadi atau hal-hal yang ia ketahui". Sedangkan menurut Sugiyono (2008:199) "Angket atau kuesioner merupakan tehnik pengumpulan data yang dilakukan dengan cara memberi seperangkat pertanyaan atau pernyataan tertulis kepada responden untuk dijawab".

Kuesioner atau angket yang digunakan dalam penelitian ini adalah jenis kuesioner atau angket langsung yang tertutup karena responden hanya tinggal memberikan tanda pada salah satu jawaban yang dianggap benar.

2. Wawancara

Wawancara dilakukan sebagai pendukung data tertulis. Agar data yang diperoleh akurat, maka proses wawancara direkam menggunakan perekam suara. Wawancara dalam penelitian ini menggunakan metode wawancara semi terstruktur, dimana menurut Sugiono (2011:317) dimana wawancara semi terstruktur, pelaksanaannya lebih bebas jika dibandingkan dengan wawancara terstruktur. Tujuan wawancara jenis ini adalah untuk menentukan permasalahan secara lebih terbuka, dimana pihak yang diwawancarai diminta pendapat dan ide-idenya. Dalam melakukan wawancara ini, pendengar secara teliti dan mencatat 
apa yang dikemukakan oleh narasumber.

Data dari metode kuisiner dan wawancara kemudian dilakukan triangulasi data. Sehingga mempeloleh kesimpulan mendeskripsikan program kerja smootie dan ice cream sayur.

\section{F. Analisis data}

Dalam penelitian ini, analisis data menggunakan penelitian kualitatif menurut Miles dan Huberman seperti yang dikutip oleh Salim (2006:20-24), menyebutkan ada tiga langkah pengolahan data kualitatif, yakni reduksi data (data reduction), penyajian data (data display), dan penarikan kesimpulan (conclusion drawing and verification).

1. Reduksi Data

Data-data yang diperoleh dari kuisioner dan wawancara kemudian direduksi untuk selanjutnya dilakukan melakukan pemilihan dan pemusatan perhatian untuk penyederhanaan, abstraksi, dan transformasi data kasar yang diperoleh dari catatan-catatan data dilapangan

2. Pemaparan Data

Pada tahap ini, peneliti menyajikan data yang berupa hasil dari tahapan reduksi. Data dikategorikan serta disajikan dalam bentuk teks deskriptif sehingga memungkinkan peneliti untuk menarik kesimpulan dari data tersebut.

3. Penarikan Kesimpulan/verifikasi

'Penarikan kesimpulan didasarkan padahasil analisis terhadap data yang telah dipaparkan dan dibahas secara jelas berdasarkan hasil kuisioner dan wawancara. Selanjutnya, penarikan kesimpulan ini ditunjukkan untuk mendeskripsikan program kerja smootie dan ice cream sayur.

\section{HASIL DAN PEMBAHASAN}

\section{A. HASIL}

Hasilnya adalah kegiatan yang berupa pendemostrasian pembuatan smoothie danice cream sayur khususnya sayur sawi yang dilakuakn di Balai Desa Kepuh Kemiri yang diikuti oleh ibu - ibu warga desa Kepuh Kemiri, sebagian besar adalah ibu - ibu PKK. Pelaksanaan ini berjalan lancar sesuai dengan yang diharapkan. Berdasarkan angket dan wawancara yang telah dilakukan yang berisi tentang minat ibu - ibu warga desa Kepuh Kemiri untuk mengikuti kegiatan ini dan belajar mencoba dan membuat sendiri, didapatkan hasil sebagai berikut:

\section{Ibu - Ibu Peserta Kegiatan Demo \\ Pembuatan Smoothie dan Ice Cream Sayur}

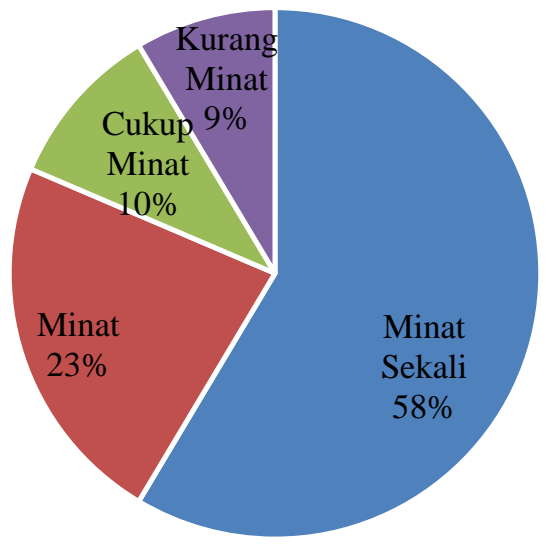

Dari diagram diatas, dapat dikatakan bahwa sebanyak $58 \%$ ibu-ibu minat sekali dalam kegiatan smootie dan ice cream sayur ini, sebanyak 23\% ibu-ibu minat dalam kegiatan ini, sebanyak $10 \%$ cukup minat dalam kegiatan, dan sebanyak $9 \%$ kurang minat dengan kegiatan smootie dan ice cream sayur ini. Sehingga dari penjabaran diatas dapat disimpulkan bahwa banyak ibu-ibu yang berminat dalam program smootie dan ice cream sayur ini karena mereka dapat membuat inovasi sayuran serta dapat meningkatkan perekonomian keluarga.

\section{B. PEMBAHASAN}

Setelah melalui beberapa langkah dan prosedur ternyata sawi dapat diinovasikan menjadi beberapa produk makanan yang berkualitas, enak, sehat dan pastinya mampu memiliki nilai jual. Di gemari konsumen terutama anak - anak. 
Beberapa dari anak - anak tidak menyukai sayur karena rasanya, tetapi dengan adanya inovasi untuk mengolah sayuran menjadi smoothie dan ice cream diyakini dapat membuat anak - anak lebih suka sayur karena rasanya enak, olahanya unik dan tampilannya juga menarik.

Dengan adanya pengolahan sayur menjadi smoothie dan ice cream mengajarkan ibu - ibu untuk menjadi lebih inovatif dalam mengolah sayur. Dapat menghasilkan produk makanan olahan sayur yang bernilai jual tinggi. Dengan modal awal yang tergolong rendah dapat menghasilkan produk yang memiliki daya tarik untuk dipasarkan ke konsumen.Setidaknya setelah diproses menjadi smoothie dan ice cream, sayur tersebut memiliki harga jual lebih tinggi dari pada dijual ke tengkulak dalam bentuk mentah. Sehingga dapat meningkatkan perekonomian masyarakat Kepuh Kemiri yang sebagian besar bermata pencaharian sebagai petani sayur.

Setelah mengetahui bagaimana cara pengolahannya, fungsi, kegunaan atau manfaat dari smoothie dan ice cream sayur ini dan setelah melalui beberapa prosedur pengambilan data diketahui bahwa banyak ibu - ibu yang memiliki antusias tinggi untuk belajar mencoba dan membuat sendiri di rumah, bahkan ingin menjualnya.

Oleh karena itu, program smootie dan ice cream sayur ini dapat dikatakan selaras dengan tema KKN yaitu desaku sehat, aman, produktif, dan kreatif.

\section{KESIMPULAN}

Kesimpulan hasil pengabdian yang telah dilakukan adalah :

1. Sayuran merupakan olahan makanan yang memiliki khasiat yang berguna untuk kesehatan diantaranya membantu mengendalikan kolesterol tubuh, membantu kesehatan tulang, dan mencegah kanker.

2. Sebagian orang malas untuk berinovasi mengolah sayuran dikarenakan tidak memiliki pemahaman tentang bagaimana mengolah sayuran agar bernilai jual tinggi.
3. Cara pengolahan sayuran oleh tim KKNPPM menjadi produk Smoothie sayurdan ice cream sayur telah menarik minat dan perhatian masyarakat Desa Kepuh Kemiri, Tulangan, Sidoarjo.

4. Smootie sayur dan ice cream sayur sudah selaras dengan tema KKN yaitu desaku pintar, sehat, aman, produktif, dan kreatif sehingga dapat dirasakan manfaatnya bagi seluruh masyarakat desa.

\section{REFERENSI}

Arikunto, Suharsimi. 2006. Metodelogi penelitian.Yogyakarta: Bina Aksara.

Sugiyono. 2008. Metode Penelitian Pendidikan (Pendekatan Kuantitatif, Kualitatif, dan $R \& D)$ ). Bandung: Alfabeta.

http://darsatop.lecture.ub.ac.id/2015/11/eskrim/

http://wartamedika.com/manfaat-sayur-sawi/

https://widisudharta.weebly.com/metodepenelitian-skripsi.html

http://www.informasimu.com/2014/03/kelebi han-obat-herbal.html 